\title{
Effects of an Experimental Challenge with Mycobacterium marinum on the Blood Parameters of Nile Tilapia, Oreochromis niloticus (Linnaeus, 1757)
}

\author{
Maria José Tavares Ranzani-Paiva*, Carlos Massatoshi Ishikawa, Augusta Cocuzza das \\ Eiras and Vivian Risaffi da Silveira \\ Centro de Pesquisa e Desenvolvimento de Peixes Ornamentais; Instituto de Pesca SAA-APTA; Av. Francisco \\ Matarazzo, 455; 05001-900; São Paulo - SP - Brazil
}

\begin{abstract}
A hundred adult of tilapia, Oreochromis niloticus, were inoculated intraperitoneally with $10^{8}$ c.f.u. of Mycobacterium marinum. Other 100 speciemns were maintained without inoculation. Blood samples of six inoculated animals were collected at 01,03, 07, 14, 21, 28, 35, 42, 49, 56 and 84 days after inoculation. Initially, six specimens were taken from the non inoculated group ("time zero"). The haematological parameters determined were: haematocrit (Hct), haemoglobin concentration $(\mathrm{Hgb})$, total erythrocytes count $(\mathrm{RBC})$, hematological indexes $(\mathrm{MCV}, \mathrm{MCH}$ and $\mathrm{MCHC})$, thrombocyte count (Tr), leukocyte count (WBC) and leukocyte differential count. There were no changes in Hct, Hgb, MCH and MCHC. However, the mean values for RBC and MCV decreased. The mean values for RBC and Hct of specimens from the "time zero" group were higher and the MCV and MCH lower than in inoculated animals. Occurred neutrophilia, and, at $72 \mathrm{~h}$ there was lymphocytosis and neutropenia. By the $49^{\text {th }}$ day after bacterial inoculation, there was monocytosis.
\end{abstract}

Key words: Mycobacterium marinum, tilapia, Oreochromis niloticus, hematology

\section{INTRODUCTION}

Although teleost fishes have been widely studied, their inflammatory responses have received little attention. Mycobacteriosis is one of the various diseases that occur in fish, and is caused by bacteria belonging to the family Mycobacteriaceae. These are visually demonstrated as straight or slightly curved bacilli which have aerobic, immobile, and nonsporulating characteristics. They are acid-alcohol fast and often considered to be Gram-positive. Various mycobacteria species are ubiquitous in the environment and can be found in water, soil and dust (Ferracini, 1992). Mycobacteriosis is primarily a disease of zoonotic importance, and in humans can cause cutaneous lesions (piscine granuloma), commonly associated with professional and recreational activities.

Studies about ectothermic animals tuberculosis began in 1897 when Bataillon, Dubart and Terre (apud Inglis, Roberts and Bromage, 1994) described the disease in carp (Cyprinus carpio L.), found in ponds contaminated by human waste containing the tuberculosis bacteria. Jakowska and Nigrelli (1953) conducted an experimental study of the inflammatory process by the biological agents inoculation in fish, when they reported

*Author for correspondence 
their observations regarding the lesions induced by Mycobacterium spp. in Poecilia reticulata $\mathrm{P}$. These lesions were first characterized by an exudate composed predominantly of eosinophils, containing gross granulation and phagocytic material. After two days following the inoculation with the agent, it was detected a predominance of macrophages and the formation of granulomatous tissue.

It is known that mycobacteriosis in ectothermal organisms can be induced by parenteral injections of mycobacteria suspensions. However, the natural form of infection occurs by the ingestion of infected tissues or contaminated food (Nigrelli and Vogel, 1963).

Jaeger (1988) pointed out the importance of these effects, relating them to the relative frequency of mycobacteriosis in individuals maintained in captivity, due to the inadequate conditions in which they were kept.

In Brazil, there have been some reports of mycobacteriosis in amphibians (Barros et al., 1988, Souza et al., 1990, Magalhães et al., 1992, Souza, 1993 and Moraes et al., 1996, 1997) and reptiles (Ramos, 1997). However, there are few reports of the occurrence of this disease in fishes (Couto and Araújo, 1983). Therefore, further studies are needed to before we can understand the occurrence and consequences of mycobacteriosis in fish kept in capitivity in Brazil with the aim of preserving the health of both farmed fish and consumers.

There is a growing interest in the Nile tilapia, Oreochromis niloticus, culture in Brazil. In 1996, this species represented $32 \%$ of Brazilian farmed production, increasing this peak in 1998 to 35\%, or 35,000 tonnes/year (Agriculture Ministery, Brazil, 2002). The popularity of this fish is rapidly growing throughout the world; which has now been recognized in many regions as an excellent food source.

The use of haematological parameters as fish health indicators has been proposed by Hesser (1960). Since then, many investigators have examined the physicochemical composition of fish blood as it reflects the individual physiological state at a given time. As modern biologists discover the necessity to conduct blood studies to learn more about organisms physiological response to a pathogenic agents, more clear becomes the importance of hematology relating to disease.
The aim of this study was to investigated the effects of an experimental challenge with Mycobacterium marinum on the blood parameters of Nile tilapia, Oreochromis niltoticus.

\section{MATERIAL AND METHODS}

A total of 200 Nile tilapia, Oreochromis niloticus (mean length of $15.27 \mathrm{~cm}$ and mean weight of 54.21 $\mathrm{g}$ ), stocked in earth ponds of the Experimental Station of Pindamonhangaba, Fishery Institute, State of Sao Paulo, Brazil were utilized. Following the transfer to 3,000 liter aquaria, at a $23{ }^{\circ} \mathrm{C}$ temperature, 100 fish were inoculated intraperitoneally with $10^{8}$ c.f.u. of Mycobacterium marinum (ATCC 927) cultivated in LöweinsteinJensen for eight days at $30^{\circ} \mathrm{C}$. The bacterial culture was dilluted in a saline solution $(0.85 \%)$, outlined in Ishikawa (1998). Another 100 fishes were kept without inoculation. The inoculation in this study was based on Hatai et al. (1988), Kawakami and Kusuda (1990) and Talaat et al. (1997).

Six inoculated fishes were utilized for each sampling. Blood samples were collected at $24 \mathrm{~h}$ and $72 \mathrm{~h}$, and every 7 days after the inoculation for the first 8 weeks and then at the $84^{\text {th }}$ day, totalizing 11 samples. Initially, 6 specimens were taken from the non inoculated group and considered as "time zero". The fishes were anesthetized with benzocaine at a concentration of $100 \mathrm{mg} / \mathrm{L}$ (Green, 1979), and blood was withdrawn from the caudal peduncule. The haematocrit (Hct) was determined by the microhaematocrit method according to Goldenfarb et al. (1971), and haemoglobin concentration $(\mathrm{Hgb})$ by the cyanomethaemoglobin method (Collier, 1944). The erythrocyte count or total cell number (RBC) and total leukocyte count (WBC) were determined using a Neubauer chamber with Natt and Hedrick (1952) solution as dilutant. The haematological indeces, mean corpuscular volume (MCV), mean corpuscular haemoglobin $(\mathrm{MCH})$ and mean corpuscular haemoglobin concentration (MCHC) were calculated according to Wintrobe (1934).

The differential leukocyte count and the total thrombocyte count (Tr) were carried out using blood smears stained according to the Rosenfeld (1947) method. To prevent blood coagulation disposable syringes and needles were heparinized. Following examination, the specimens were euthanized by cerebral comotion. The biological 
data were recorded $(\mathrm{Wt}$ - total weight in grams and $\mathrm{Lt}$ - total length in $\mathrm{cm}$ ) and a ventral incision was made to expose the visceral organs.
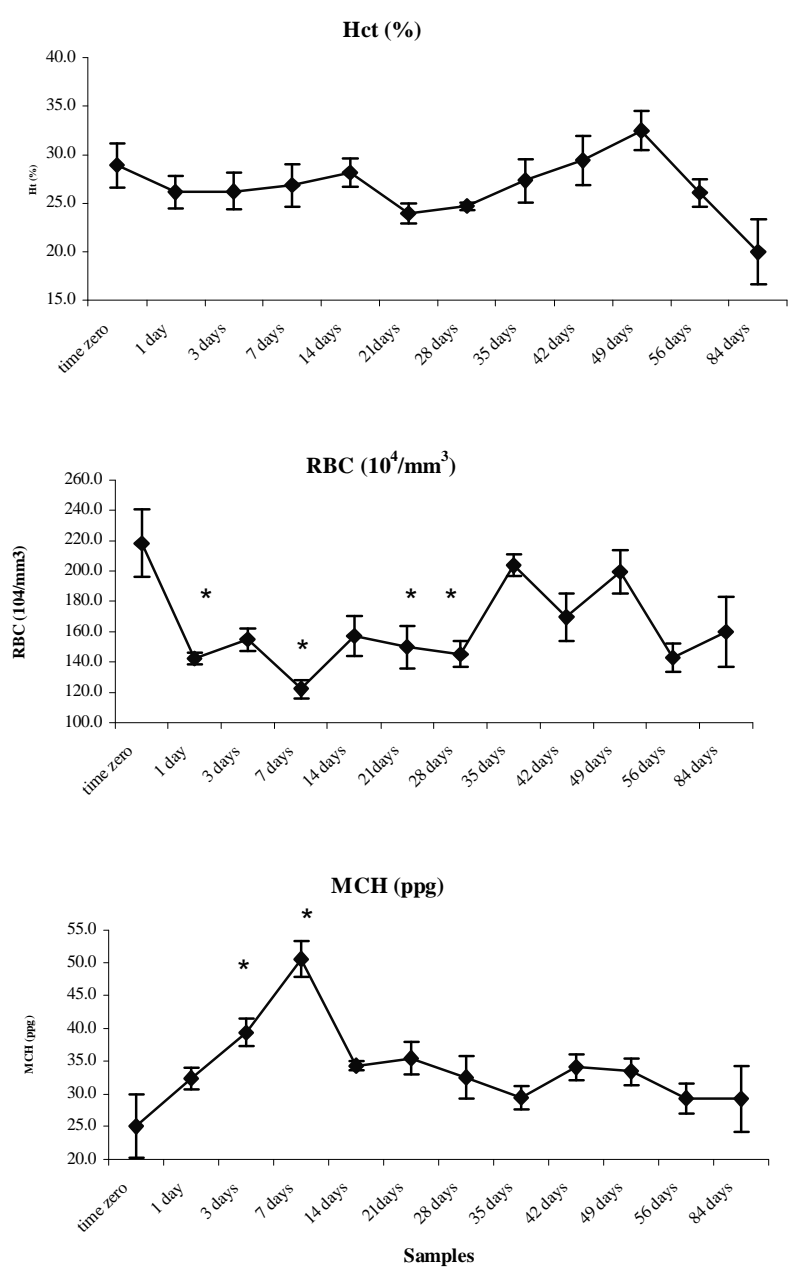

The means and standard error of means of each haematological parameter were calculated, and analysis of variance (ANOVA) was used to evaluate differences among these data.
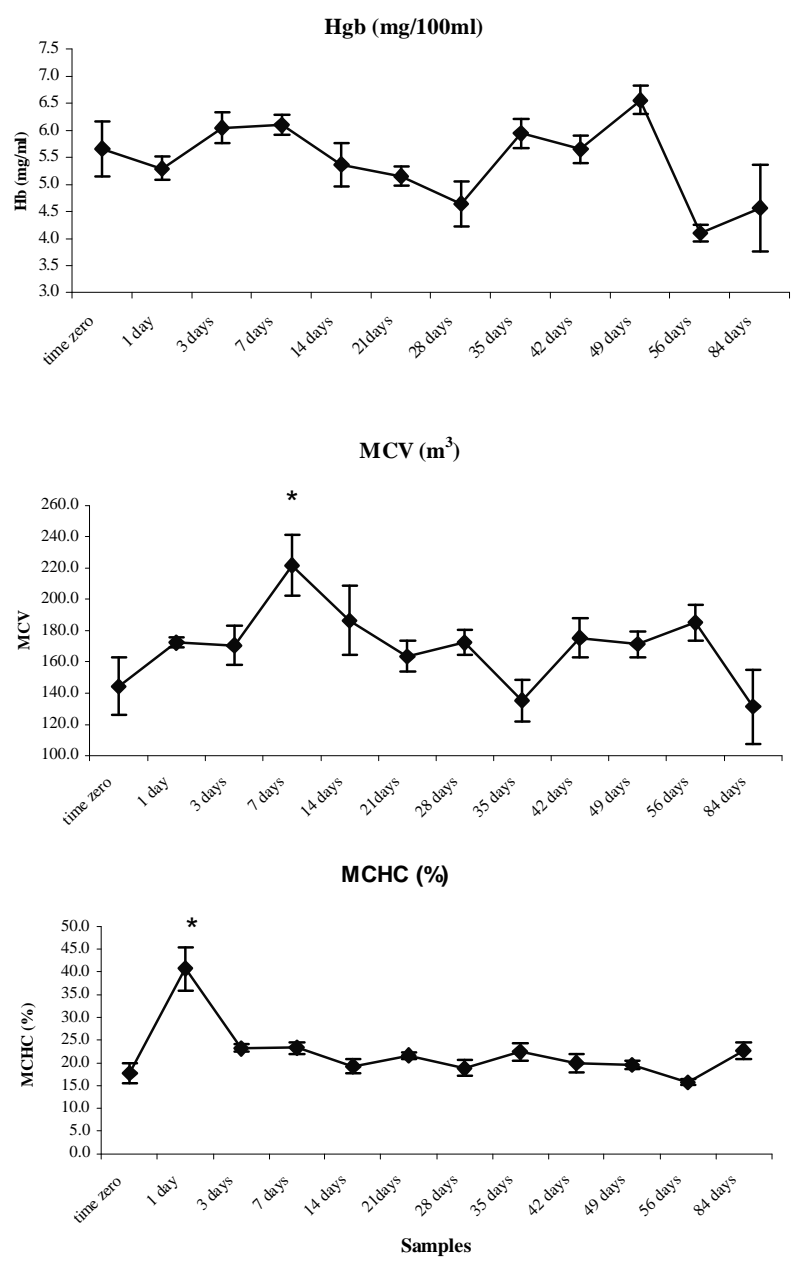

Figure 1 - Mean values of blood parameters of Oreochromis niloticus experimentally inoculated with Mycobacterium marinum

$\mathrm{Hct}=$ haematocrit $\mathrm{RBC}=$ erythrocyte count $\mathrm{Hgb}=$ haemoglobin level $; \mathrm{MCV}=$ mean corpuscular volume;
$\mathrm{MCH}=$ mean corpuscular haemoglobin; $\mathrm{MCHC}=$ mean corpuscular haemoglobin concentration
* Significantly different from the time zero

\section{RESULTS}

The inoculated fishes did not show clinical signs of mycobacteriosis during the experimental period. Based on the analysis of variance (ANOVA), the haematological parameters $\mathrm{RBC}, \mathrm{MCV}, \mathrm{MCH}$, $\mathrm{MCHC}$ and $\mathrm{WBC}$, of some sampling time were significantly different from the "time zero" animals $(\mathrm{p}<0.05)$.
Figure 1 showed that the mean values for Hct, $\mathrm{Hgb}$ and $\mathrm{RBC}$, more or less constant at the start, were markedly elevated by the end of the experiment. These values were reflected in the haematological indices, such as the increase in the number of erythrocytes with a lower cell volume and consequently, a lowered cellular haemoglobin content, thus maintaining a constant concentration. 
The absolute numbers of thrombocytes and leukocytes at different times are represented in Figures 2 and 3. Figure 2 showed that there was a large oscillation in thrombocyte counts among the first samplings. At day 28 after inoculation, however, the number of thrombocytes decreased substantially with a tendency to return to normal levels in subsequent samplings.

Inoculated fishes showed leukocytosis mainly due to neutrophilia and slight lymphocytosis after one day, which was characteristic of an acute infection (Fig. 3). However, after 3 days the occurrence of lymphocytosis and neutropenia was noted suggesting that a serious infection process took place. Monocyte counts increased at days 14 and 35 and remained high until day 45. At the end of the experiment, the mean values of each type of leukocyte were close to those of fish at time zero. In a kinetic study conducted with inoculated fish, mycobacteria was present in variable and irregular quantities in the blood (Ishikawa, 1998).
Eosinophils were seen only in one animal 14 days after the inoculation, and therefore these do not appear in the Figure 3.

The blood of the inoculated fishes showed marked morphological abnormalities typical of immature cells. These changes comprised greater cytoplasmic vacuolization in monocytes compared to the non inoculated group and toxic cytoplasmic granulations in neutrophils. At the $6^{\text {th }}$ sampling (28 days), the neutrophils showed an intensive cytoplasmic basophilia, and at the $9^{\text {th }}$ week (49 days), the monocytes showed numerous vacuoles and were comparatively bigger than those of monocytes from preceding samplings. Vacuolization was also observed in the cytoplasm of lymphocytes and neutrophils (Fig. 4), predominantly in the last sampling. Differences between means for the different types of leukocytes were significant, except for eosinophils and basophils compared among each other.

\section{Thrombocytes}

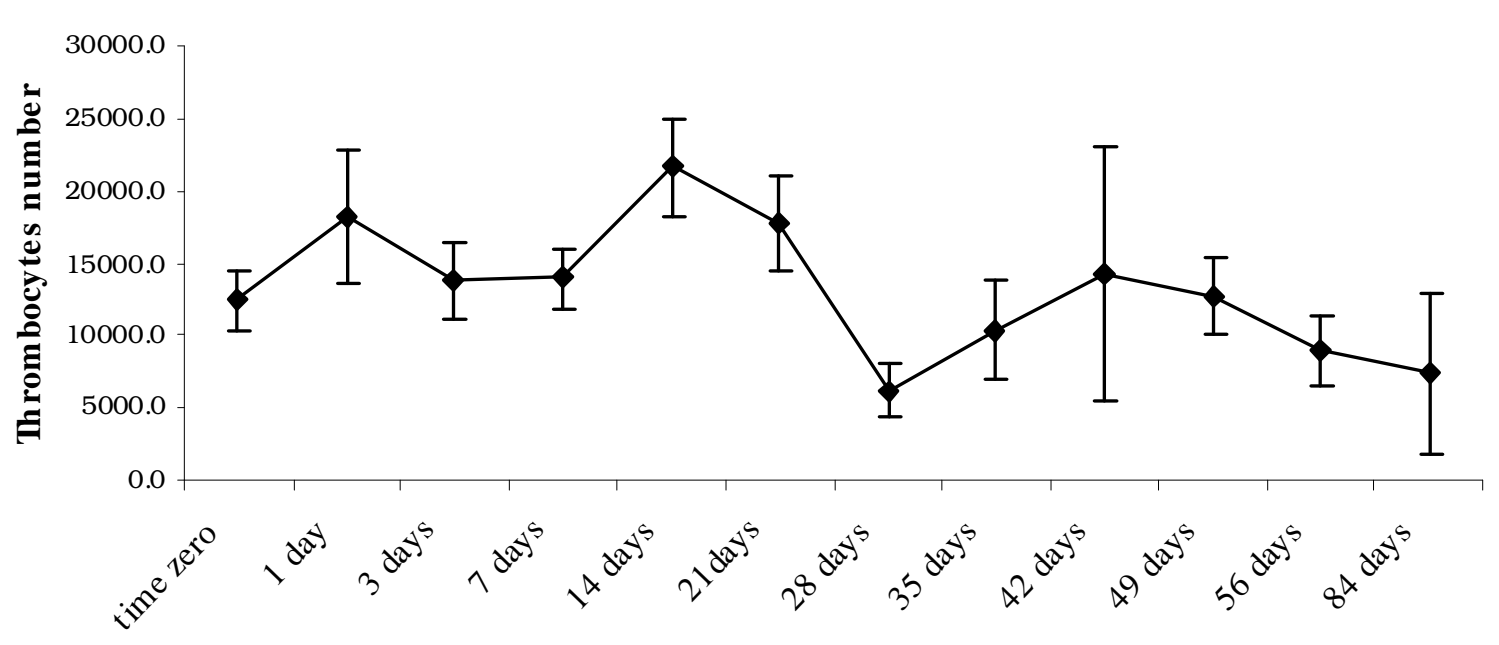

\section{Samples}

Figure 2 - Mean values of the number of thrombocytes versus sampling of Nile tilapia (O. niloticus) experimentally inoculated with Mycobacterium marinum 


\section{Total and Differential leukocyte counts}

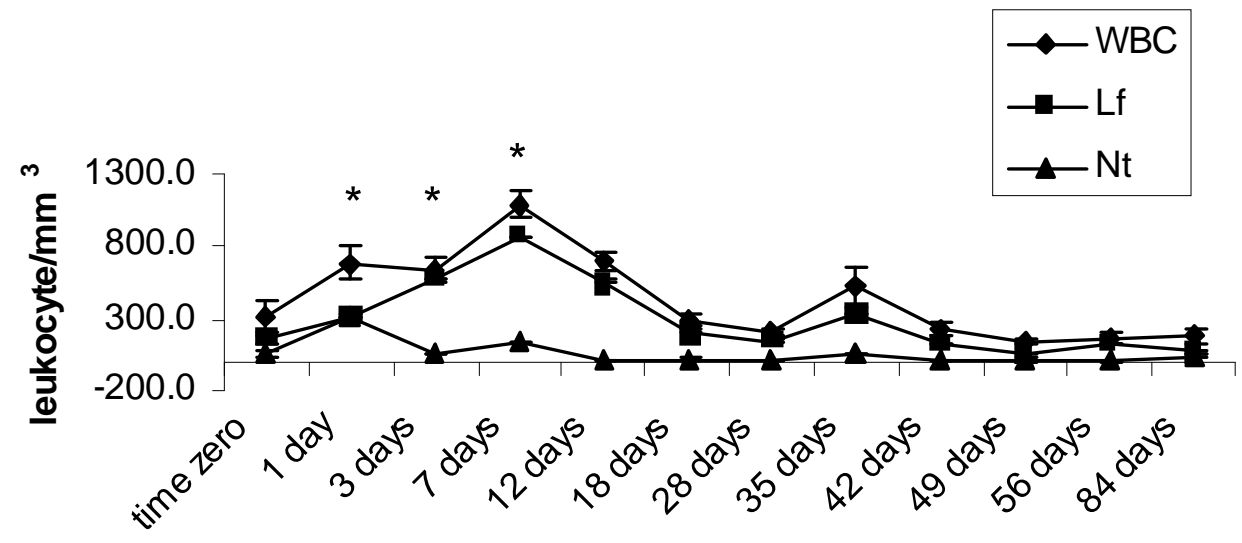

Samples

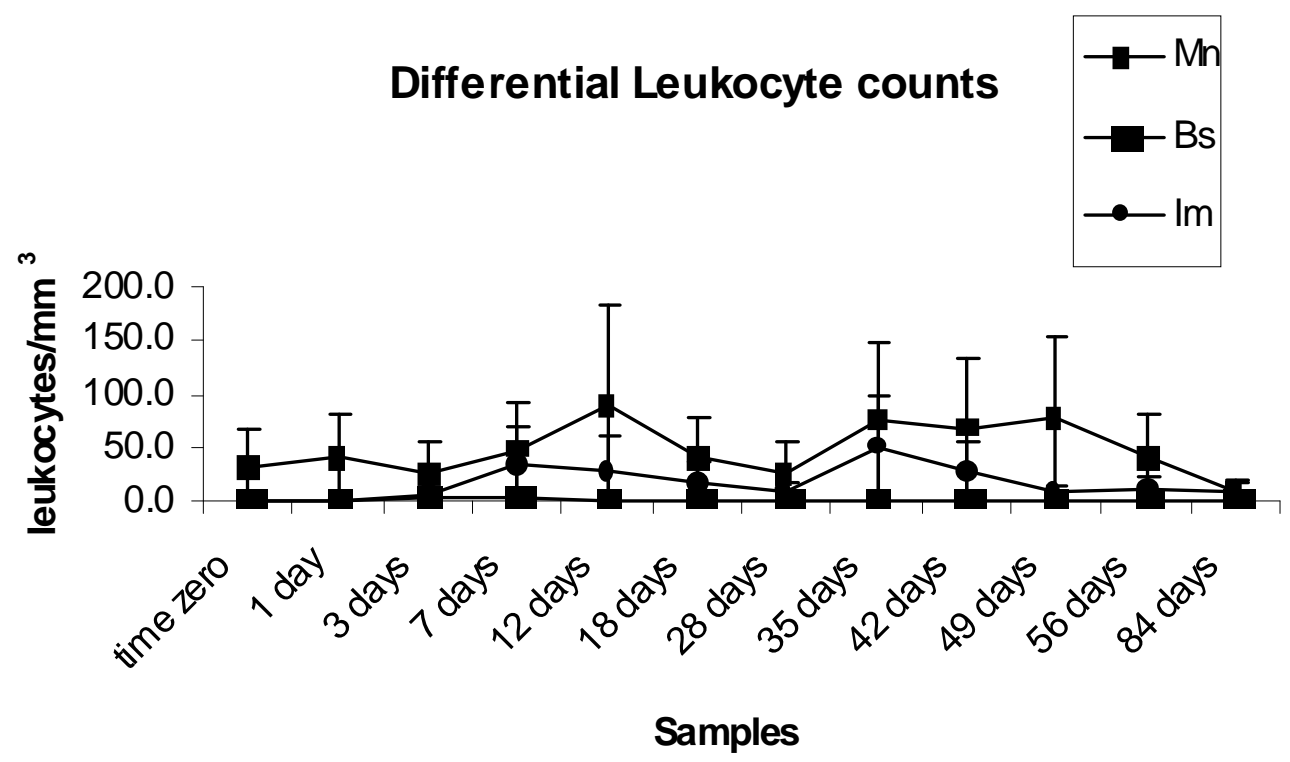

Figure 3 - Mean values of leukocytes number in peripheral blood of Oreochromis niloticus experimentally inoculated with Mycobacterium marinum

$\mathrm{WBC}=$ total leukocyte count Lymph = lymphocytes; $\mathrm{Neu}=$ neutrophils; Mono= monocytes; Baso = basophils; $\mathrm{Im}=$ immature cells

* Significantly different from the time zero 


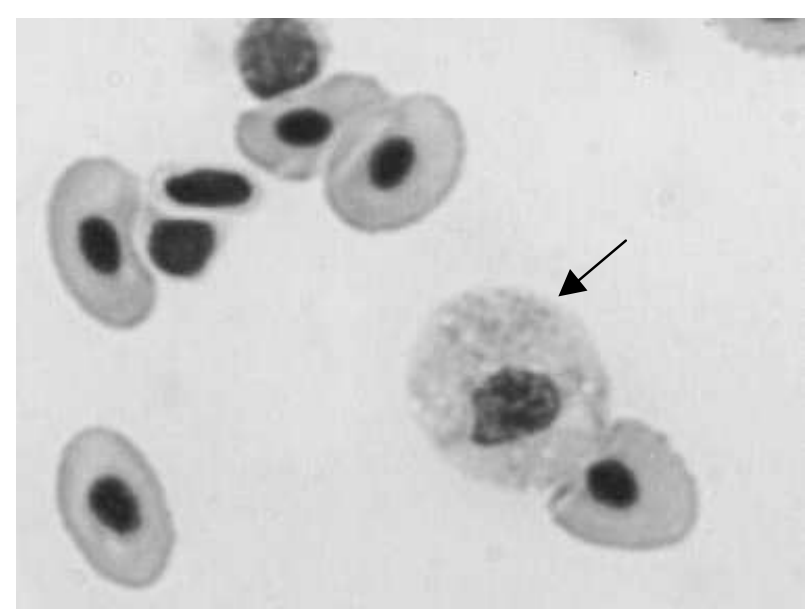

Figure 4 - Neutrophil of $O$. niloticus experimentally inoculated with Mycobacterium marinum, showing citoplasmatic vacuolization (arrow). Rosenfeld (1000X).

\section{DISCUSSION}

Mycobacteriosis is a chronic progressive disease. Clinical manifestations of this disease in fish include lethargy, anorexy, fin and scale loss, exophthalmia, emaciation, skin inflammation and ulceration, edema, peritonitis and nodules in muscles, which may deform the fish (Stoskopf, 1992). However, these signs of disease were not observed in tilapia in the present study, even though the growth of bacterial colonies was found in the internal organs (liver, spleen and kidney) by Ishikawa (1998), confirming the presence of infection. Nigrelli and Vogel (1963) presented a list of 151 fish species diagnosed with mycobacteriosis and later Dulin (1979) also acepted that any species of fish was susceptile to this infection. In 1990, Noga et al. found samples of adult Oreochromis mossabicus raised in an aquarium with clinical signs of mycobacteriosis. However, no report was found relating haematological analysis an $M$. marinum in fish.

The values of the haematological parameters found for the time zero group were quite similar to both reported by Ranzani-Paiva et al. (1998) for Nile tilapia obtained from a natural habitat and by Tavares-Dias et al. (2000) for the hybrid Florida red tilapia, Oreochromis urolepis hornorum X $O$. mossambicus, under intensive rearing. The haematological parameters for intraperitoneally inoculated Nile tilapia with $M$. marinum showed very significant variations during the course of the experiments. Based on the haematological indeces it was evident that these changes occured mainly during the first week following inoculation.

Barham et al. (1980) and Brenden and Huizinga (1986) also showed that infected fishes have more circulating immature erythrocytes than the healthy ones. The decrease in the erythrocytes number and the haematocrit of tilapia inoculated with $M$. marinum could suggest, as similarly in birds (Hawkey et al., 1990), a tendency to develop hypochromic, microcytic anaemia.

Observations made in this study indicated that most of the haematological parameters were altered by the disease. Ishikawa (1998), showed that the spleen, liver and kidney of unhealthy fish held fairly severe infection, suggesting that haematopoiesis was also severely affected and this affected the peripheral blood by decreasing erythrocyte volume.

Regarding fish, the role of the thrombocytes in the inflammatory process is still unknown. According to Matushima and Mariano (1996), these cells participate, together with the lymphocytes, directly in the granulomatous reaction. According to Finn and Nielson (1971) thrombocytes are present in recent fish lesions, more as a secundary cell type rather than one playing an active role. In the present study, thrombocyte counts were altered, decreasing shortly after fish inoculation, when numerous bacterial colonies were seen within organs. Lester and Budd (1979), in fishes experimentally inoculated with Vibrio spp., found thrombocytes, neutrophils and monocytes, apparently with phagocyted bacteria.

Finn and Nielson (1971) observed in Salmo gairdneri (= Oncorhynchus mykiss) a slight neutrophilia soon after the injection with complete Freund's adjuvant or a saline suspension of heatkilled Staphylococcus aureus. This occurred between $12 \mathrm{~h}$ and 2 days with a peak at $24 \mathrm{~h}$. Macrophage (monocytes) counts increased at day 4 and remained elevated. In the present paper, neutrophilia occurred initialy, however, without an increase in the number of immature cells, which was characteristic of a chronic infection process.

Some changes were noticed in the morphology of leukocytes of $O$. niloticus during the course of the infection process. After the $4^{\text {th }}$ sampling (14 days), it was noted that some immature neutrophils showed toxic granulations, similar to those described by Hine and Wain (1988). By the $6^{\text {th }}$ sampling (28 days), neutrophils showed an intense cytoplasmatic basophilia and in the $9^{\text {th }}$ week 
(49 days), monocytes showed numerous vacuoles and were comparatively larger than the monocytes in preceeding samplings. Vacuolization was also observed in the cytoplasm of lymphocytes and neutrophils mainly in the last sampling. In mammals, the elements frequently referred as "toxic" neutrophils are indicative of serious infection and a severe inflammatory condition. "Toxic" neutrophils are characterized by cytoplasmic basophilia, prominent toxic granulation, loss of nuclear chromatin differentiation and vacuolization of the cytoplasm (Canonino et al., 1979 apud Hine and Wain, 1988 and Hawkey et al., 1990). These characteristics could also be associated with immature neutrophils (cytoplasmic basophilia and no nuclear differentiation); however the release of immature neutrophils into the circulatory system is generally accompanied by neutrophilia, in fishes as well as in mammals, and it is a nonspecific response to stress, such as in inflammation and diseases (Brenden and Huizinga, 1986). The increase in neutrophils represents a nonspecific immune response to the bacterial infection. Hine and Wain (1988) also observed in eels (Anguilla anguilla L.) injected with bacterial lipopolysaccarides the presence of neutrophils, these were intensively basophilic, more vacuolized and frequently found with an undifferentiated nucleus.

According to Janini and Janini $F^{\text {o. }}$ (1992), in a specific inflammatory process there is an initial phase with normal red blood cell values and neutrophilia, eosinophilia, lymphocytosis and monocytosis associated with structural modifications of the monocytes. Brenden and Huizinga (1986) noted a marked change in a predominance of lymphocytes to a predominance of neutrophils which then persisted in the blood of Carassius auratus L., $12 \mathrm{~h}$ after being experimentally inoculated with Aeromonas hydrophila.

The dynamics of the inflammatory reaction represents important aspects of immunity. Factors influencing this response may have a significant effect on resistance to disease. Mac Arthur et al. (1984) studied the migration of leukocytes from the blood and organs into sites of tissue damage, in Pleuronectes platessa $\mathrm{L}$. injected intraperitoneally with either oyster glycogen or live Vibrio alginolyticus, observing an acute cellular inflammatory response. The inflammatory response was biphasic with a peak in the neutrophil number and total leukocyte count on the second day, with a following peak of macrophages on the seventh day after inoculation.

Some haematological changes, including monocytosis, have been described in domesticated birds with avian tuberculosis. Monocytes and total leukocyte numbers were found to increase in $92 \%$ of the cases, while heterophilia was seen in $81 \%$, lymphocytosis in $39 \%$, eosinophilia in $42 \%$, basophilia in $19 \%$, and thrombocytosis in $50 \%$ of the birds (Hawkey et al., 1990).

In another case, buffaloes inoculated with Mycobacterium bovis, Kumar and Parihar (1998) found significant reduction of RBC, Hct, $\mathrm{Hgb}$ and neutrophil percentages, followed by a slight increase with the progression of the disease. A slight reduction in the thrombocyte count also appeared to be an integral cause in the deteriorating health of the animals following onset and progression of infection. The lymphocyte percentage fluctuated during the course of the disease but these changes were not significant. Monocyte levels were found to increase significantly towards the later stage of the disease.

\section{CONCLUSIONS}

The inoculation of $O$. niloticus with $M$. marinum did not significantly alter the red blood cell series of the fish. However, there was a discreet hypochromic, microcytic anemia. The leukocytes, however, showed a variation in number, characterized initially by an acute inflammatory reaction and a consequent chronicity. Although these results were not conclusive, they might have greater practical significance in the diagnosis of this disease.

\section{RESUMO}

Cem exemplares adultos de tilápia, Oreochromis niloticus, foram inoculadas intraperitonealmente com $10^{8}$ UFC de Mycobacterium marinum e outras 100 foram mantidas sem inoculação. Inicialmente, o sangue de 6 exemplares não inoculados foi colhido e considerado como "tempo zero". Do grupo dos inoculados foi retirado sangue de 6 animais por colheita, 1, 3, 7, 14, 21, 28, 35, 42, 49, 56 e 84 dias após inoculação. Os parâmetros hematológicos: hematócrito (Hct), taxa de hemoglobina (Hgb), contagem de eritrócitos (RBC), 
foram determinados e os índices hematológicos (VCM, HCM e CHCM), calculados. Foram determinados também o número de trombócitos e o número total e diferencial de leucócitos. Não ocorreram alterações nos valores de Hct, Hgb, HCM e CHCM. Entretanto houve diminuição dos valores de RBC e VCM. Os valores médios de RBC e Hct dos animais no "tempo zero" foram maiores e os de VCM e HCM, menores que os dos animais inoculados. Ocorreu neutrofilia e, após 3 dias de inoculação, ocorreram linfocitose e neutropenia nos animais. No $49^{\circ}$. dia após inoculação bacteriana, ocorreu monocitose.

\section{REFERENCES}

Agriculture Ministery, Brazil (2002), Disp. in: http:lwww.agricultura.gov.br. Viewed in : 30 mar. 2002.

Barham, W. T.; Smit, G. L. and Schoonbee, H. J. (1980), The effect of bacterial infection on erythrocyte fragility and sedimentation rate of rainbow trout, Salmo gairdneri Richardson. Journal of Fish Biology, 16, 177-180.

Barros, G. C.; Langenergger, C. H.; Langenergger, J. and Peixoto, P. V. (1988), Surto de micobacteriose em criação de rãs (Rana catesbeiana) causado por Mycobacterium marinum. Pesquisa Veterinária Brasileira, 8, 75-80.

Brenden, R. A. and Huizinga, H. W. (1986), Pathophysiology of exprimental Aeromonas hydrophila infection in goldfish, Carassius auratus. Journal of Fish Diseases, 9, 163-167.

Collier, H. B. (1944), The standardization of blood haemoglobin determinations. Canadian Medical Association Journal, 50, 550-552.

Couto, L. M. M. R. and Araújo, M. G. M. F. (1983), Um caso de tuberculose espontânea de tainha, Mugil curema Valenciennes, 1836 (Pisces, Mugilidae), no canal de Santa Cruz. In: III COMBEP, Manaus, Brazil. pp. 457-465.

Dulin, M. P. (1979), A review of tuberculosis (mycobacteroisis) in fish. Veterinary Medicine/Small animal Clinician,74, 731-735.

Ferracini Jr., R. (1992), Avaliação de técnicas de descontaminação empregadas no isolamento de micobactérias a partir de águas. M.Sc. Thesis, Instituto de Biociências, UNESP - Rio Claro, Brazil.

Finn, J. P. and Nielson, N. O. (1971), The inflammatory response of rainbow trout. Journal of Fish Biology, 3, 463-478.

Goldenfarb, P. B.; Bowyer, F. P.; Hall, E. and Brosius, E. (1971), Reproducibility in the hematology laboratory: The micro-haematocrit determinations. American Journal of clinic Pathology, 56, 35-39.
Green, C. J. (1979), Animal anesthesia. London: Laboratory animal LTD, The British Council. pp. 111-129.

Hatai, K.; Lawhavinit, O.; Kubota, S. S.; Toda, K. and Suzuki, M. (1988), Pathogenicity of Mycobacterium sp isolated from pejerey, Odonthestes bonariensis. Fish Pthology, 23 : (3), 155-159.

Hawkey, C.; Kock, R. A.; Henderson, G. M. and Cindery, R. N. (1990), Haematological changes in domestic fowl (Gallus gallus) and cranes (Gruiformes) with Mycobacterium avium infection. Avian Pathology, 19, 223-234.

Hesser, E. F. (1960), Methods for routine on fish hematology. The Progressive Fish Culturist, 22, 164-171.

Hine, P. M. and Wain, J. M. (1988), Characterization of inflammatory neutrophils induced by bacterial endotoxin in the blood of eels, Anguilla australis. Journal of Fish Biology, 32, 579-592.

Inglis, V.; Roberts, L. J. and Bromage, M. L. (1994), Diseases of fish. Cambridge : The University Press. $312 \mathrm{pp}$.

Ishikawa, C. M. (1998), Quantificação bacteriana e avaliação das lesões em peixes da espécie Oreochromis niloticus (Tilápia do Nilo) inoculados experimentalmente com Mycobacterium marinum ATCC 927. M.Sc. Thesis. University of São Paulo. São Paulo, Brazil.

Jaeger, J. (1988), Die Tuberkulose der Aphibien. Kleintierpraxis, 32, 319-320.

Janini, P. and Janini, F. P. (1990), Interpretação clínica do hemograma. 10. ed. São Paulo : Sarvier. 625 pp.

Jakowska, S. and Nigrelli, R. F. (1953), Localized response to experimental inflammation caused by pathogenic bacteria. Anatomy Records, 117, 526.

Kawakami, K. and Kusuda, R. (1990) Efficacy of rifampicin, streptomycin and erythromycin against experimental mycobacterium infection in cultured yellow tail. Bulletin of Japanese Society of Scientific Fisheries, 56 : (1), 51-53.

Kumar, G.S. and Parihar, N. S. (1998), Haematobiochemical picture in buffaloes induced with Mycobacterium bovis. Indian Journal of Animal Science, 68, 923-924.

Lester, R. J. G. and Budd, J. (1979), Some changes in the blood cells of diseased coho salmon. Canadian Journal of Zoology, 57, 1458-1464.

Mac Arthur, J. I.; Fletcher, T. C.; Pirie, B. J. S.; Davidson, R. J. L. and Thomson, A. W. (1984), Peritoneal inflammatory cells in plaice, Pleuronectes platessa L: effects of stress and endotoxin. Journal of Fish Biology, 25, 69-81.

Magalhães, H.; Carneiro, G. M.; Pires, A. R.; Madeiros, M. I. M.; Gonçalves, W. M.; Santiago, S. S. F.; Silva, L. S. and Mello, S. C. R. P. (1992), Micobacteriose em rãs touro (Rana catesbeiana Shaw, 1802). In:. Encontro Nacional de Ranicultura, 7., Rio de Janeiro. Proceeding... Rio de Janeiro. pp. 278. 
Matushima, E. R. and Mariano, M. (1996), Kinetics of the inflammatory reaction induced by carregenin in the swim bladder of Oreochromis niloticus (Nile Tilapia). Brazilian Journal of veterinary Research and animal Science, 33, 5-10.

Moraes, J. R. E.; Martins, M. L.; Moraes, F. R.; Souza Jr., F. and Souza, V. N. (1997), Micobacteriose em Rana catesbeiana Shaw, 1802 oriundas de ranários comerciais. In: Encontro Nacional de Ranicultura, and Technofrog, Santos. Proceeding... Santos. pp. 211.

Moraes, J. R. E.; Torres, H. A.; Martins, M. L.; Souza, V. N. and Moraes, F. R. (1996), Tuberculose em Rana catesbeiana Shaw, 1802, em ranários comerciais diagnosticado pelo Centro de Aquicultura da UNESP. In: Encontro Brasileiro de Patologia de Organismos Aquáticos, Pirassununga. Proceeding... Pirassununga. pp. 28.

Natt, M. P. and Herrick, C. A. (1952), A new blood diluent for counting the erythrocytes and leukocytes of the chicken. Poultry Science, 31, 735-738.

Nigrelli, R. F. and Vogel, H. (1963), Spontaneous tuberculosis in fishes and in other cold-blooded vertebrates with special reference to Mycobacterium fortuitum Cruz from fish and human lesions. Zoologica, 48, 130-143.

Noga, E.J.; Wright, J.F. and Passarell, L. (1990) Some unusual features of mycobacteriosis in ciclid fish Oreochromis mossambicus. Journal of Comparative Pathology, 102 : (3), 335-344.

Ramos, M. C. C. (1997), Avaliação de aspectos morfológicos, histoquímicos, imunohistoquímicos $e$ ultraestruturais do processo inflamatório crônico, induzido experimentalmente pela inoculação de Mycobacterium marinum vivo e morto pelo calor em tartarugas tracajá Podocnemis unifilis Troschel, 1848. Ph.D. Thesis. University of São Paulo, São Paulo, Brazil.

Ranzani-Paiva, M. J. T.; Eiras, A. C. and Felizardo, N. N. (1998), Análises hematológicas em tilápia-do-Nilo, Oreochromis niloticus da Represa de Guarapiranga, São Paulo. In: Reunião Anual do Instituto de Pesca, São Paulo. Proceeding... São Paulo. pp. 5.

Rosenfeld, G. (1947), Corante pancrômico para hematologia e citologia clínica. Nova combinação dos componentes do May-Grünwald e do Giemsa num só corante de emprego rápido. Memórias do Instituto Butantan, 20, 329-334.

Souza, C. W. O. (1993), Ocorrência de Mycobacterium sp. em exemplares de Rana catesbeiana, Shawn, 1802, de alguns ranários comerciais do Estado de São Paulo, Brasil. M.Sc.Thesis. Federal University of Santa Catarina, Florianópolis, Brazil.
Souza, C. W. O.; Macruz, R.; Martins, M. L. and Souza Jr., F. L. (1990), Ocorrência de lesões cutâneas na região do crânio de imagos de rã-touro (Rana catesbeiana Shaw, 1802). Histopatologia. In: Encontro Brasileiro de Patologia de Organismos Aquáticos. São Paulo. Proceeding... São Paulo. pp. 31.

Stoskopf, M. (1992), Bacterial diseases of freshwater tropical fishes. In: Fish Medicine. W. B. Saunders Company. pp. 559-561.

Talaat, A.; Deng, Y.; Reimschuessel, R. and Trucksis, M. (1997), Mycobacterium marinum and goldfish, Carassius auratus a model system for mycobacterial pathogenesis. In: General Meeting Abstracts. American Society of Microbiology. pp. 562.

Tavares-Dias, M.; Frascá-Scorvo, C. M.; Novato, P. F. C. and Moraes, F. R. (2000), Haematological characteristics of hybrid Florida red tilapia, Oreochromis urolepis hornorum O. mossambicus under intensive rearing. In: International Symposium on tilapia Aquaculture, 5., Rio de Janeiro. Proceeding... Rio de Janeiro. pp. 533-541.

Wintrobe, M. M. (1934), Variations in the size and haemoglobin content of erythrocytes in the blood of various vertebrates. Folia Hematologica, 51, 32-49.

Received: November 19, 2002; Revised: December 11, 2003; Accepted: June 29, 2004. 